\title{
Record of Short Finned Eel from Nagata River, Shimonoseki, Japan*1
}

\author{
Osame TABETA, ${ }^{* 2}$ Toru TAKaI, ${ }^{* 2}$ and Isao Matsui*3
}

(Received June 2, 1976)

\begin{abstract}
Three specimens of short finned eel, 70.5-81.0 $\mathrm{mm}$ in total length, were found in the samples collected in Nagata River, Shimonoseki, Japan, on July 9, 1974. They have a total vertebral count of 114-117, predorsal 36 and 38 , preanal 37 and 39 , ano-dorsal 0 and 1 , abdominal 44 and 45 , and caudal 69 and 72 , being easily distinguishable from the other specimens. Closer examination of this exotic eel revealed that they are tentatively referable to Anguilla australis Richardson, which is known only from the southern hemisphere. These youngs are considered to be derivatives from the imported elvers for eel culture.
\end{abstract}

The authors found three specimens of exotic eel in the collection of young eels from Nagata River, Shimonoseki, Japan, in July 1974. Closer examination of the specimens revealed that they are tentatively referable to the short finned eel Anguilla australis RICHARDSON. Various species of the short finned eels are distributed in the Philippines and southward, ${ }^{1-3)}$ although a single record for $A$. bicolor MCCLELLAND, a short finned species, is known from Fusan, South Korea. ${ }^{4}$ A considerable amount of anguillid elvers consisting of more than ten species has been imported into Japan from various countries since 1968 , because the recent poor catch of elvers has brought a serious shortage of the seed for eel culture. It is said that some of these imported elvers were released into rivers and lakes to increase the eel population. The present three specimens are considered to be derivatives from such imported elvers. In this paper the authors describe the present specimens and tentatively identify them to species.

\section{Materials and Methods}

Some 330 young eels, $70-136 \mathrm{~mm}$ in total length, were collected for the purpose of rearing experiments in the middle course (about one $\mathrm{km}$ from the mouth) of the Nagata River, which is a small river, about $3.7 \mathrm{~km}$ in length, flowing into the Sea of Hibiki-nada at Shimonoseki, on July 9, 1974. Of these young, the present three specimens were noted for their peculiarity in external morphology. They were examined under binocular microscope following the methods adopted by $\mathrm{EGE}^{1 /}$ and TABETA et al. ${ }^{5)}$ Vertebral counts were defined on the X-ray photograph.

*1 Contribution from the Shimonoseki University of Fisheries, No. 774

*2 Department of Aquiculture \& Biology, Shimonoseki University of Fisheries, Yoshimi, Shimonoseki, Japan (多部田修・高井 徹: 水産大学校增嘶学科)

*3 Ube Junior College, Ube, Yamaguchi Pref., Japan. (松井 越：宇部短期大学) 


\section{Observation and Discussion}

The external morphology and X-ray photograph of the anterior part of the present specimens along with those of $A$. japonica TEMMINCK et SCHLEGEL collected together are shown in Figs. 1 and 2. The measurements and vertebral counts are tabulated in Table 1.
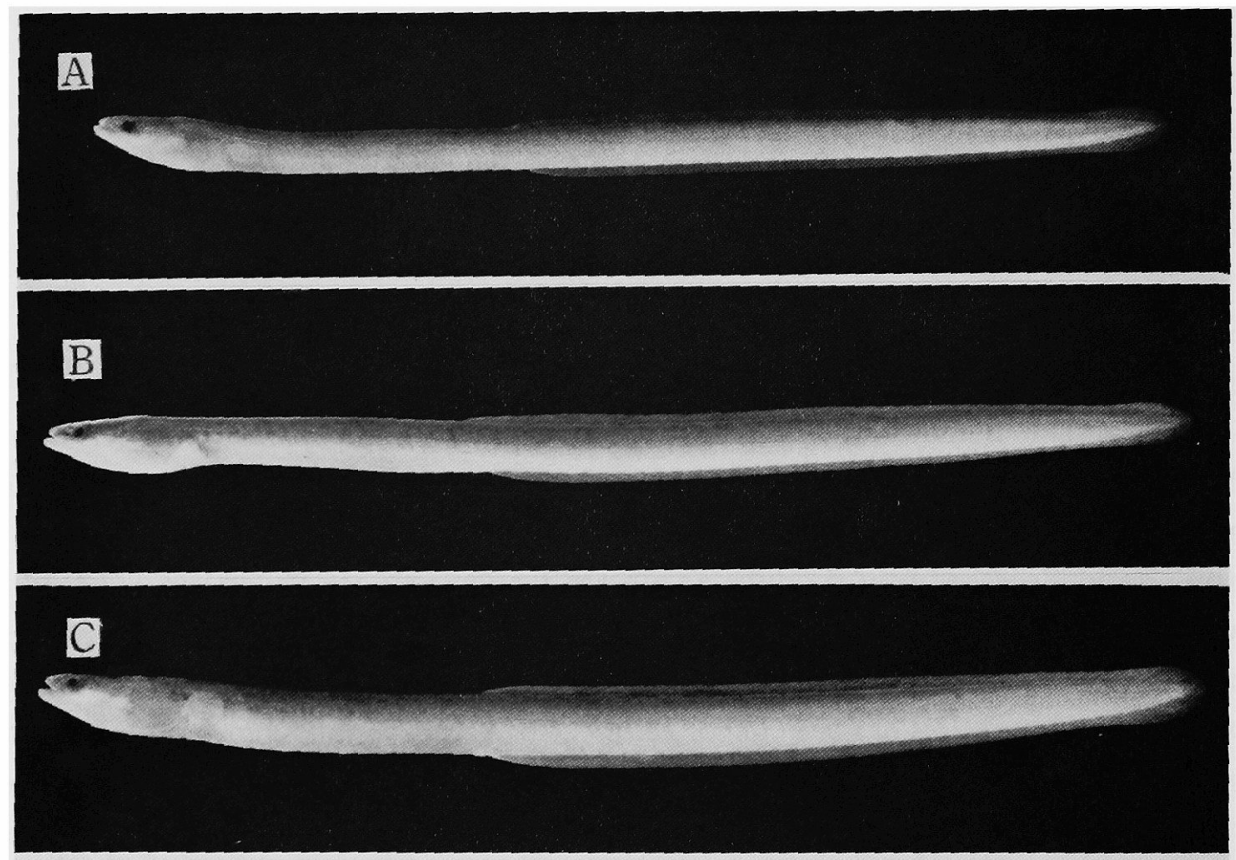

D

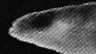

Fig. 1. Short finned eel (Anguilla australis Richardson, A-C) and long finned eel (A. japonica Temminck et Schlegel, D) from Nagata River, Shimonoseki, Japan. A, $70.5 \mathrm{~mm}$ in total length; $\mathrm{B}, 80.5 ; \mathrm{C}, 81.0 ; \mathrm{D}, 80.5$.

The brief description given below is based on a specimen of $81.0 \mathrm{~mm}$ in total length (Cat. SUF Na-103). Body elongate, rather robust, with the greatest depth (about $6 \%$ of the total) at the posterior part of pectoral base. Maxillary, intermaxillary and vomerine band of teeth not developed, only two or three tiny teeth visible. Origin of dorsal located at $38 \%$ of the total, placed nearly opposite to anus. Pectoral large (about $27 \%$ of the head), rounded in shape with 17 rays; dorsal rays about 245 , anal about 210 , caudal 9 . Lateral line conspicuous in the anterior part of dorsal origin. 


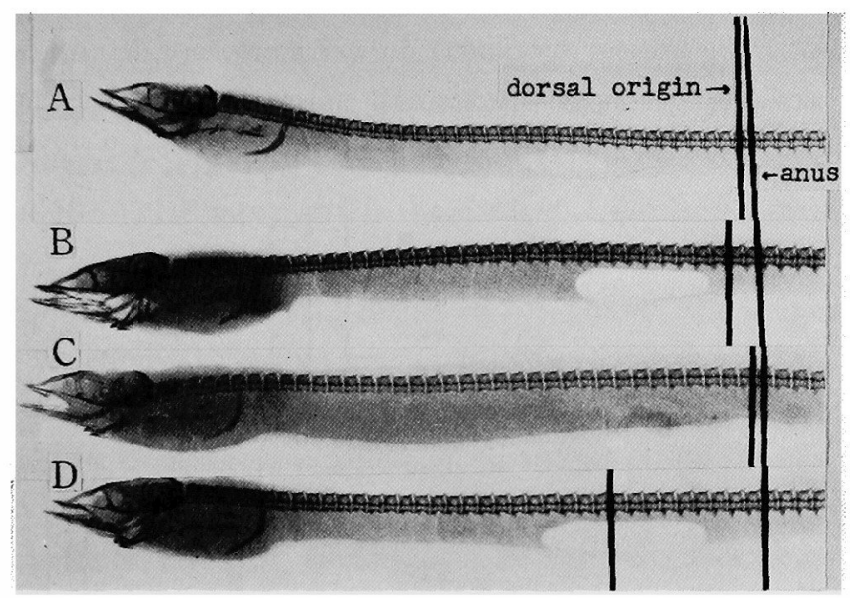

Fig. 2. X-ray photograph of the eels. Marks are same as those in Fig. 1.

Table 1. Measurements and counts of the short finned eel from Nagata River, Shimonoseki, Japan

\begin{tabular}{lccc}
\hline Cat. SUF & Na-101 & Na-102 & Na-103 \\
\hline Total length & $70.5 \mathrm{~mm}$ & $80.5 \mathrm{~mm}$ & $81.0 \mathrm{~mm}$ \\
Standard 1. & 69.5 & 79.4 & 80.0 \\
Head l. & 8.7 & 10.0 & 10.0 \\
Snout 1. & 1.5 & 1.7 & 1.4 \\
Eye diameter & 0.8 & 0.8 & 1.0 \\
Upper jaw 1. & 2.1 & 2.4 & 2.2 \\
Lower jaw l. & 2.3 & 2.6 & 2.3 \\
Predorsal l. & 27.5 & 29.5 & 31.0 \\
Preanal l. & 28.0 & 30.5 & 30.7 \\
Ano-dorsal l. & 0.5 & 1.0 & 0.3 \\
Interorbital width & 1.5 & 1.7 & 1.8 \\
Body depth & 3.0 & 4.0 & 4.6 \\
Total vertebrae & & & 114 \\
Predorsal v. & 117 & 116 & 36 \\
Preanal v. & 38 & 36 & 37 \\
Ano-dorsal v. & 39 & 37 & 0 \\
Abdominal v. & 0 & 1 & 65 \\
Caudal v. & 45 & 74 & 69 \\
\hline
\end{tabular}

Color in formalin dark above, paler below; tip of lower jaw also dark; pectoral and anal pale, dorsal and caudal slightly dark.

The present specimens are easily distinguishable from $A$. japonica, which is collected together in the river, in having a long predorsal and short ano-dorsal length, and large number of predorsal and small number of ano-dorsal vertebrae (Figs. 3 and 4). Anodorsal length (less than $1.2 \%$ of the total) and number of ano-dorsal vertebrae (less than one) of the specimens indicate that they are the short finned eels. ${ }^{1,5}$ An eel culturist 
informed us that such "deformed" eels are seen quite exceptionally in the eel pond, but they do not grow. The present specimens do not show any deformity in both body proportion and skeleton. Eighteen species and subspecies of eels are recognized from the world, of which 5 species and subspecies are short finned eels., ${ }^{1,6}$ Vertebral counts

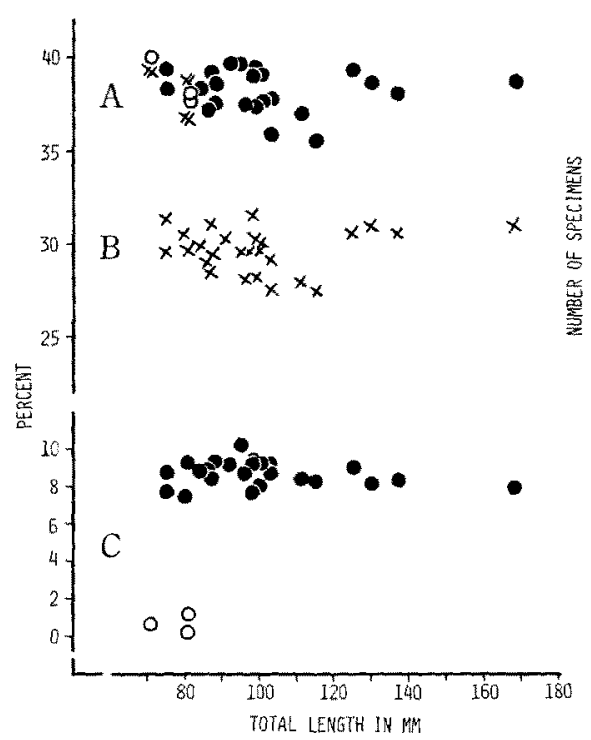

Fig. 3.
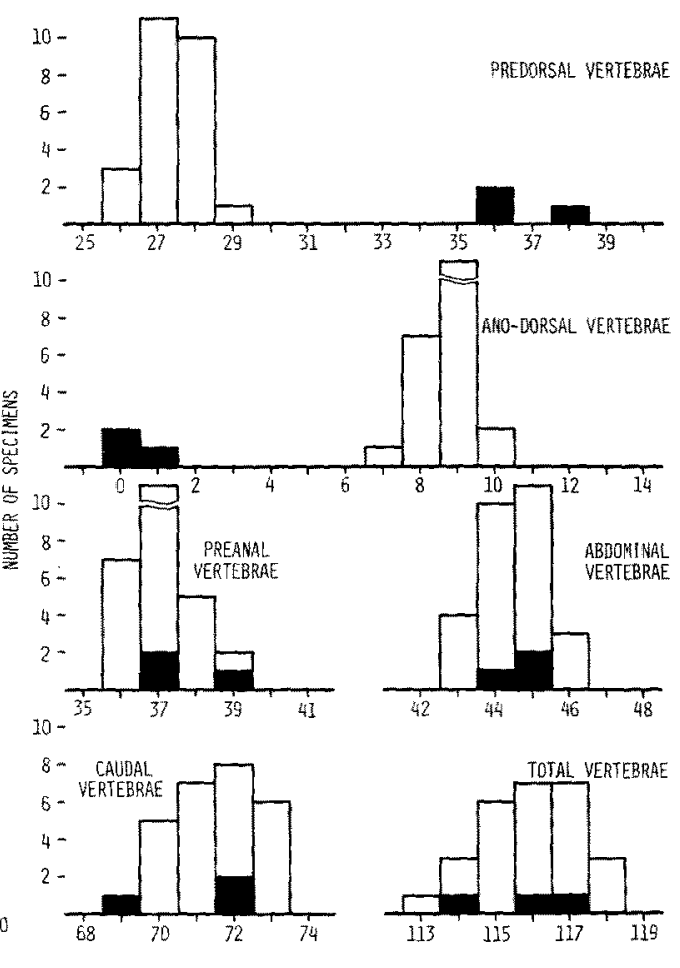

Fig. 4.

Fig. 3. Body proportions in two eels.

A, preanal length/total length: $O$, A. australis; $\bullet$, A. japonica.

B, predorsal length/total length: $\not x$, A. australis; $\times$, A. japonica.

$\mathrm{C}$, ano-dorsal length/total length: $\mathrm{O}$, A. australis; $\bullet$, A. japonica.

Fig. 4. Sectional counts of vertebrae in two species.

Black, A. australis; white, A. japonica.

Table 2. Vertebral counts of the short finned eels (EGE, 1939; figures in parentheses from TABETA et al., 1976).

\begin{tabular}{lcc}
\multicolumn{1}{c}{ Species } & Abdominal & Total \\
\hline A. obscura & $40-43$ & $101-107$ \\
A. bicolor bicolor & $41-45$ & $106-115$ \\
& $(41-43)$ & $(106-110)$ \\
A. bicolor pacifica & $41-45$ & $103-111$ \\
& $(44,45)$ & $(107-112)$ \\
A. australis australis & $44-48$ & $109-116$ \\
A. australis schmidti & $44-48$ & $108-115$ \\
& $(45-47)$ & $(110-116)$ \\
\hline
\end{tabular}


of the short finned species are shown in Table 2. In the present specimens as seen in Table 1, this character agrees with that of $A$. australis RICHARDSON (total vertebrae 108$116^{1,7,8)}$ ), except for a specimen having total vertebrae 117 (Cat. SUF Na-101). Recently, SHOJIMA $^{9)}$ obtained total vertebrae 113-121 (60 specimens examined) in the elvers of $A$. japonica from Nagasaki to the ever known range $112-119^{1,3,10)}$; TABETA et al.$^{57}$ reported also total vertebrae 107-112 (8 specimens) in the elvers of $A$. bicolor pacifica ScHMIDT from Malaysia to the ever known range 103-11 ${ }^{11}$, and 110-116 (13 specimens) in the elvers of $A$. australis schmidti PHILlIPPs from New Zealand to 108-115, ${ }^{1,7}$. Consequently, the speci men having total vertebrae 117 should appear hereafter in A. australis. The authors, therefore, identified tentatively the present specimens as $A$. australis. Color patterns of the specimens agree well with those of young of the species (unpublished). The authors could not identify them to the subspecies level, because they are undeveloped in both external and internal morphology. A. australis is known from the southern hemisphere (Australia, New Zealand, New Caledonia, etc.). This eel was already introduced into Taiwan as food fish from Australia before 1967.11) In Japan the elvers of this species have been annually imported as seed for culture (Custom Statistics). In fact the elvers were reared in the eel ponds of northern Kyushu in 1973 and 1974. The present specimens are considered to be derivatives from such imported elvers. Although the authors made several collections in the neighbouring rivers in 1974-1976, only the Nagata River yielded specimens of $A$. australis. The whereabouts of other imported elvers in natural conditions in Japan currently studied will be discussed in another paper.

\section{Acknowledgements}

The authors express their gratitude to Mr. Tsutomu TaNimoto, student of our University for help in collecting the samples, and Dr. P. H. J. CASTLE, Department of Zoology, Victoria University of Wellington, New Zealand, for his kind inspection of the manuscript.

\section{References}

1) V. EGE: Dana-Rep., 16, 1-256 (1939).

2) A. W. HerRE: Fish and Wildlife Service, United States Department of the Interior, Research Report, 20, 1-977 (1953).

3) I. Matsur: Eel biology; A biological study, Koseisha-Koseikaku, Tokyo, 1972, pp. 1-15; 48-75 (In Japanese).

4) T. MorI: Check list of the fishes of Korea, Mem. Hyogo Univ. Agr., 1 (Biol. Ser. No. 1), 1-228 (1952).

5) O. TABETA, T. TAKAI and I. Matsur: Japan. J. Ichthyol., 22, 195-200 (1976).

6) P. H. J. Castle and G. R. Williamson: Copeia, 1974, 2, 569-570 (1974).

7) J. Scrumpt: Trans. New Zealand Inst., 58, 379-388 (1927).

8) J. SCrMidT: Rec. Australian Mus., 15, 179-210 (1928).

9) Y. ShoJma: Zool. Mag. (Dobutsugaku Zasshi), 76, 167-171 (1967) (In Japanese). 
10) C. Ishukawa and N. Takahashi: Note on the eels of Japanese, Corean, Formosan and adjacent water, J. Coll. Agr., Imperial Univ. Tokyo, 4, 415-433 (1914).

11) J. T. F. Chen and H. T. C. Weng: A review of the apodal fishes of Taiwan, Dep. Biol., Coll. Sci., Tunghai Univ., Biol. Bull., 32, 1-86 (1967). 